\title{
Economic assessment of geothermal district heating systems: A case study of Balcova-Narlidere, Turkey
}

\author{
Berkan Erdogmus ${ }^{\mathrm{a}}$, Macit Toksoy ${ }^{\mathrm{a}}$, Baris Ozerdem ${ }^{\mathrm{a}, *}$, Niyazi Aksoy $^{\mathrm{b}}$ \\ ${ }^{a}$ Department of Mechanical Engineering, Faculty of Engineering, Izmir Institute of Technology, Urla 35430, Izmir, Turkey \\ ${ }^{\mathrm{b}}$ Torbali Vocational School, Dokuz Eylul University, Izmir, Turkey \\ Received 17 November 2005; received in revised form 27 December 2005; accepted 2 January 2006
}

\begin{abstract}
Geothermal energy is an important renewable energy resource in Turkey. The aim of this research is to evaluate the Balcova-Narlidere geothermal district heating system from an economic perspective. The system is the largest one in Turkey in terms of heating capacity and located in Izmir. Although there are some assessments regarding energy and exergy analysis for the Balcova-Narlidere geothermal district heating system, an economic assessment was not performed, previously. The profitability of the investment is investigated by using internal rate of return method. Seven hundred and eighty different scenarios are developed in this assessment. In order to estimate the potential cash flows in the remaining project life, operating cost in 2002 is decreased and increased, alternatively, between 5\% and 30\% by 5\% in each step, while monthly energy utilization price is changed between US\$ 17 and 72 in those scenarios. The energy utilization prices are suggested according to zero IRR value for all scenarios due to the consideration of social and environmental concerns in this investment. It is found that, the proper monthly energy utilization price for a $100 \mathrm{~m}^{2}$ household would be US\$ 55.5 when the operating cost and heating capacity in 2002 were remained constant.
\end{abstract}

(C) 2006 Elsevier B.V. All rights reserved.

Keywords: Geothermal district heating; Internal rate of return; Economic assessment

\section{Introduction}

Geothermal energy is recognized as one of the significant renewable energy resources to meet increasing energy demand of the world. Systems, using geothermal energy, are made up of three main elements: a heat source, a reservoir, and a fluid [1]. In geothermal systems, heat is recovered from hot subsurface formations with the help of meteoric water, which circulates down through the fractures and pores in the rocks. It absorbs the heat and returns to the surface with elevated temperature. Geothermal energy utilization applications have been recently subject to growing attention because of their minimum negative environmental impact, low operating cost, decentralized production advantages, and simplicity of their technologies. Geothermal energy utilization can be categorized in two groups with regard to the temperature of geothermal resources: electricity generation and direct use [2]. Space heating, domestic water heating, greenhouse heating, $\mathrm{CO}_{2}$ and dry

\footnotetext{
* Corresponding author. Tel.: +90 232 7506519; fax: +90 2327506505.

E-mail address: barisozerdem@iyte.edu.tr (B. Ozerdem).
}

ice production, and balneological use of geothermal fluids are the well-known direct use applications [3]. In general, lower geothermal fluid temperatures are required for direct use. Geothermal resources having fluid temperatures between 90 and $150{ }^{\circ} \mathrm{C}$ are suitable for district heating in which heat is distributed to a large number of individual houses or blocks of buildings from a central location, through a network of pipes $[4,5]$. Geothermal resources having fluid temperatures above $150{ }^{\circ} \mathrm{C}$ are mainly used to generate electricity.

Turkey is poor in fossil fuel resources but rich in renewable resources such as geothermal, solar, biomass, wind, and hydraulics. The wide spread volcanism and femoral hydrothermal alterations indicate significant existence of geothermal resources in Turkey. One hundred and seventy geothermal fields and about one thousand thermal and mineral water springs with a temperature range of $40-242{ }^{\circ} \mathrm{C}$ have been discovered in Turkey which is located on Mediterranean sector of Alpine-Himalaya belt [6]. This land is very active with earth crust movements, tectonic movements of the rock formations, and volcanic activities [7,8]. According to the resource assessment, which has been done by the Mineral Research and Exploration Directorate of Turkey, the geothermal resources in the country are mostly 
Table 1

The major city based geothermal district heating applications in Turkey

\begin{tabular}{|c|c|c|c|c|c|c|}
\hline Item no. & Name & $\begin{array}{l}\text { Year } \\
\text { commissioned }\end{array}$ & $\begin{array}{l}\text { Inlet } \\
\text { temperature }\left({ }^{\circ} \mathrm{C}\right)\end{array}$ & $\begin{array}{l}\text { Outlet } \\
\text { temperature }\left({ }^{\circ} \mathrm{C}\right)\end{array}$ & $\begin{array}{l}\text { Maximum mass } \\
\text { flow rate }(\mathrm{kg} / \mathrm{s})\end{array}$ & $\begin{array}{l}\text { Potential } \\
(\mathrm{MW})\end{array}$ \\
\hline 1 & Gonen, Balikesir & 1987 & 75 & 45 & 110 & 13.8 \\
\hline 2 & Simav, Kutahya & 1991 & 100 & 50 & 125 & 26.2 \\
\hline 3 & Kirsehir & 1994 & 54 & 49 & 270 & 5.6 \\
\hline 4 & Kizilcahamam, Ankara & 1995 & 70 & 42 & 150 & 17.6 \\
\hline 5 & Balcova, Narlidere, Izmir & 1996 & 118 & 60 & 294 & 71.3 \\
\hline 6 & Afyon & 1996 & 90 & 45 & 180 & 33.9 \\
\hline 7 & Kozakli, Nevsehir & 1996 & 92 & 52 & 100 & 16.7 \\
\hline 8 & Sandikli, Afyon & 1998 & 70 & 42 & 250 & 29.3 \\
\hline 9 & Diyadin, Agrı & 1998 & 86 & 73 & 200 & 10.9 \\
\hline 10 & Salihli, Manisa & 2002 & 98 & 40 & 70 & 17.0 \\
\hline 11 & Saraykoy, Denizli & 2002 & 97 & 50 & 55 & 10.8 \\
\hline Total & & & & & & 253.1 \\
\hline
\end{tabular}

moderate and low-temperatured ones and located in the North Anatolia fault zone, whereas, high enthalpy fields are located on the graben structure of western Anatolia.

At the moment, there are 38 geothermal space-heating systems in Turkey. However, only eleven of them are city based geothermal district heating systems. The total capacity of eleven city based geothermal district heating systems is calculated as $253.1 \mathrm{MW}$ by using suggested method for energy production network [9]. Table 1 shows city based geothermal district heating systems with their current mass flow rates, inlet and outlet temperatures of geothermal fluid in primary heat exchangers. As it is seen from Table 1, Balcova-Narlidere geothermal district heating system is the largest one in Turkey. In this research, it is investigated whether the Balcova-

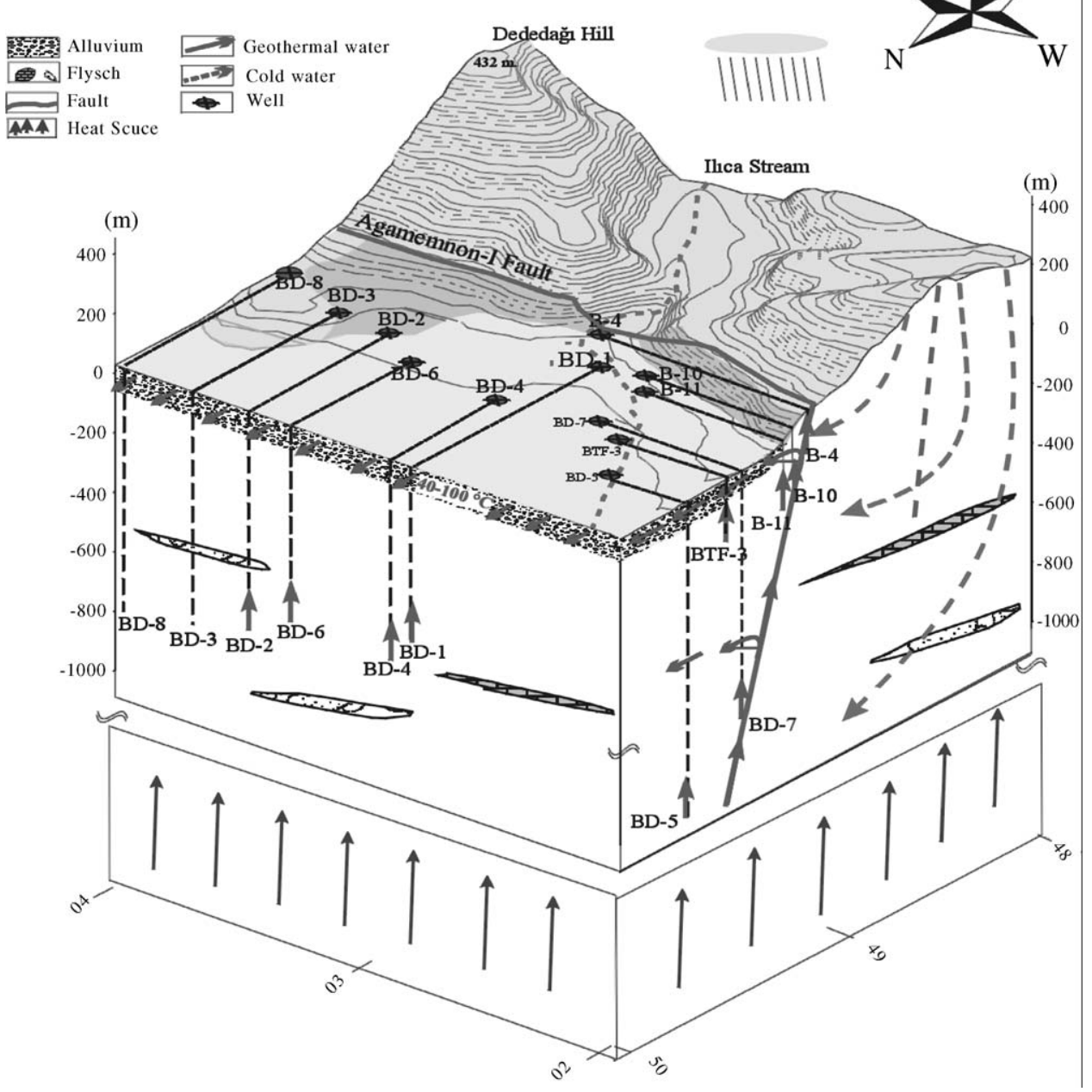

Fig. 1. The hydrogeological model of Balcova geothermal field. 
Narlidere geothermal district heating system investment is feasible in terms of economic point of view.

\section{Description of Balcova-Narlidere geothermal district heating system}

The Balcova geothermal field lies between Izmir city center and Izmir-Cesme freeway. It is located $7 \mathrm{~km}$ west from the city center and $1 \mathrm{~km}$ south from the freeway. This field covers about $3.5 \mathrm{~km}^{2}$ along the active Agamemnon fault. The thermal springs, which existed prior to the exploitation of the geothermal field are located on this fault. The Balcova geothermal field's heat flow is higher than earth's normal heat flow of $110 \mathrm{~mW} / \mathrm{m}^{2}$ [10].

Geological and hydrological studies on the field were started in 1962. Up to 1981, approximately 50 gradient, deep, and shallow wells were drilled. In 1981, since the scaling problem of geothermal fluid, downhole type heat exchangers were installed for space heating applications [11].

The wells intersect mainly lightly metamorphosed sandstones, clays and, siltstones, of the Izmir flysch sequence. The thickness of this sequence is estimated to be over $2000 \mathrm{~m}$, and in some places could be as much as $4000 \mathrm{~m}$. Deep circulating water is heated by an unidentified heat source, and then ascended through the Agamemnon fault. Fig. 1 shows the hydrogeological model of Balcova geothermal field. The well depth ranges from 45 to $1100 \mathrm{~m}$ in this field. Data recorded during 2000-2001 heating period show that the total flow rate of all the production wells was $135 \mathrm{~kg} / \mathrm{s}$ [10]. Fig. 2 illustrates the Balcova geothermal field and its well locations.
Heating capacities of production wells are calculated according to the reinjection temperature, which is $60^{\circ} \mathrm{C}$. However, some of those wells shown in Fig. 2 are not currently used. Volumetric flow rates, temperatures, heating capacities, and types of those wells are given in Table 2.

As a result of improvements on geothermal technology, a district heating system investment had been considered for the Balcova geothermal field. The construction of BalcovaNarlidere geothermal district heating system was started in 1996. The Balcova part of system started operating, partially, at the end of 1996. The Narlidere part has been operating since 1998. In 2002, new investments extended the capacity and reached the heating of $1,150,000 \mathrm{~m}^{2}$ households [12]. The total heating capacity of the production wells has reached to $72 \mathrm{MW}$ at the end of 2003.

There are three piping networks in the Balcova-Narlidere geothermal district heating system: energy production, energy distribution, and energy consumption. The energy production network is composed of wells and two parallel pipeline systems. The lineshaft pumps are installed in production wells in order to take geothermal fluid to the surface. The flow of each well is controlled from zero to maximum value by using frequency converters [13]. The geothermal fluid is pumped to a mixing chamber. It is mixed with the reinjection fluid and then transmitted to eight different heat exchanger stations by the supply lines. Geothermal fluid is not passed directly through a heating system because of its corrosive properties. Energy is transferred to the energy distribution network by the use of plate type heat exchangers, which are named as primary heat exchangers. In order to prevent corrosion problem, titanium is

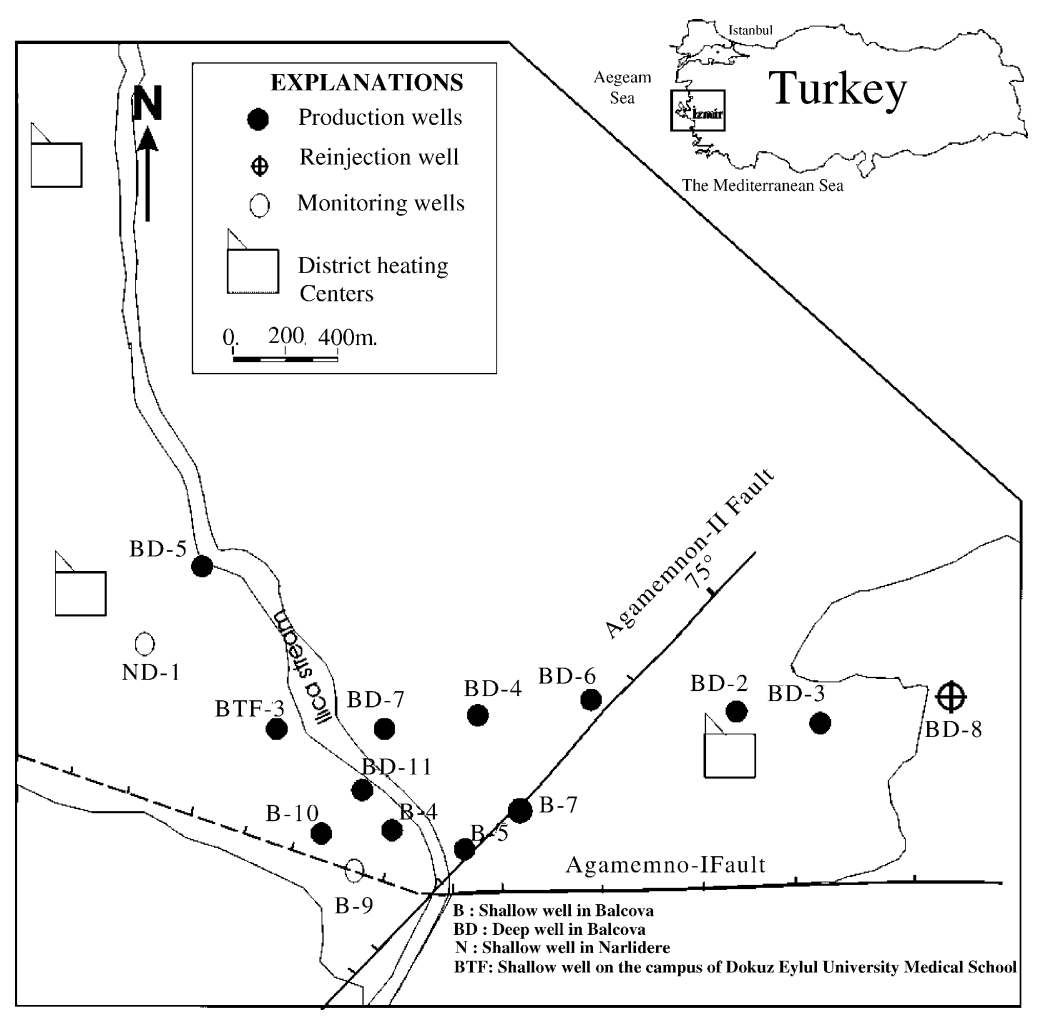

Fig. 2. The Balcova geothermal field and its well locations. 
Table 2

The temperatures and capacities of wells in Balcova geothermal field

\begin{tabular}{|c|c|c|c|c|c|}
\hline Well name & Well type & $\begin{array}{l}\text { Well } \\
\text { temperature }\left({ }^{\circ} \mathrm{C}\right)\end{array}$ & $\begin{array}{l}\text { Volumetric } \\
\text { flow rate }\left(\mathrm{m}^{3} / \mathrm{s}\right)\end{array}$ & $\begin{array}{l}\text { Mass flow } \\
\text { rate }(\mathrm{kg} / \mathrm{s})\end{array}$ & $\begin{array}{l}\text { Heating } \\
\text { capacity (MW) }\end{array}$ \\
\hline BD-2 & Production & 132 & 180 & 50 & 15.1 \\
\hline BD-3 & Production & 120 & 100 & 28 & 7.0 \\
\hline BD-4 & Production & 135 & 190 & 53 & 16.6 \\
\hline BD-5 & Production & 120 & 80 & 22 & 5.6 \\
\hline BD-6 & Production & 135 & 100 & 28 & 8.7 \\
\hline BD-7 & Production & 120 & 80 & 22 & 5.6 \\
\hline BD-8 & Reinjection & - & 600 & 164 & - \\
\hline B-4 & Production & 100 & 55 & 15 & 2.6 \\
\hline B-5 & Production & 105 & 135 & 38 & 7.1 \\
\hline B-7 & Production & 97 & 140 & 39 & 6.0 \\
\hline B-9 & Monitoring & 95 & - & - & - \\
\hline B-10 & Production & 105 & 200 & 56 & 10.5 \\
\hline B-11 & Production & 109 & 40 & 11 & 2.3 \\
\hline ND-1 & Monitoring & 115 & - & - & - \\
\hline BTF-3 & Production & 100 & 30 & 8.3 & 1.4 \\
\hline
\end{tabular}

chosen as a plate material. In addition, special chemicals called inhibitors are injected into the system. After transferring the energy, the geothermal fluid is transmitted to the re-injection well. This type of disposal method prolonged the life of the resource in Izmir. The tap water is circulated in the energy distribution network, which is about $80 \mathrm{~km}$ long. The preinsulated pipes, which minimize heat losses during transmission of hot water are used in the distribution network. The diameters of pipes in this network vary from 25 to $350 \mathrm{~mm}$ [13]. The carbon steel pipes are chosen for the geothermal transmission and distribution networks. The secondary heat exchangers are used to transfer hot tap water's energy to the water circulated in the energy consumption network. Those heat exchangers are installed at the basement of each building connected to the system. In buildings' networks, heated city water is sent to the radiators or fan coils assembled in each household. In addition to this, geothermal energy is also used to provide domestic hot water. The district heating system is presented schematically in Fig. 3.

\section{Economic assessment}

When the geothermal resource is proven in terms of temperature and flow rate, the main consideration factor becomes the economic viability of geothermal district heating system. The cost of a geothermal direct use application is influenced by the following characteristics: depth of resource, distance between resource location and application site, well flow rate, resource temperature, temperature drop, load factor, composition of fluid, ease of disposal, and resource life [14]. Capital cost could be divided into surface and subsurface costs according to economic risks in geothermal district heating system investments. The surface cost could be predicted with the same accuracy as for common civil engineering works. Therefore, the risk in surface investment is relatively small [15].

The surface cost in presented system was calculated according to the construction expenses and additional cost after the construction. During the construction of BalcovaNarlidere geothermal district heating system, the construction cost was paid to the contractor by accruals between 1996 and 1999 by the local government funding. Because of the capacity increase, additional investment was required in 2001 and 2002. The cost of additional investment was financed by equity capital, and it was categorized into two groups: costs of auxiliary equipment, and new connection lines. The subsurface cost of Balcova-Narlidere geothermal district heating system investment was very high and paid in long term. The well

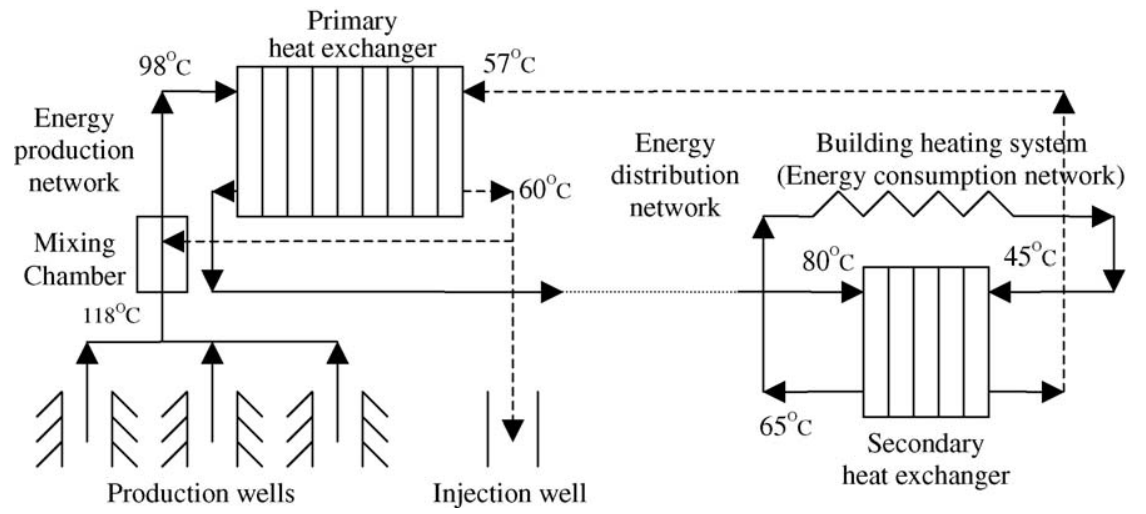

Fig. 3. Schematic representation of networks in the Balcova-Narlidere geothermal district heating system. 
drilling cost was determined in accordance with the unit cost, which was US\$ $235.70 / \mathrm{m}$ in 2002 [12]. In addition to this, operating and future investment costs, tax, and depreciation were taken into consideration while assessing the outcomes of the investment.

Operating cost was divided into seven groups: personnel, electricity, tap water, chemicals (inhibitor and other chemicals used to prevent corrosion and to clean heat exchangers), maintenance, marketing and rent of the facilities.

The main revenues in Balcova-Narlidere geothermal district heating system are subscription fee (connection charge), monthly heating fee (fix charge) and bank interest over surplus.

Main methods applied in the economic assessments are net present value (NPV), and internal rate of return (IRR). The IRR measures the rate of return of investment, whereas, NPV measures the size of the return. In this research, the IRR method was used to calculate the energy utilization fee, which makes the investment acceptable. Time value of money is taken into consideration by using the IRR method. The project life is assumed as 25 years. The IRR is a hypothetical discount rate that equates the cash inflow to cash outflow [16]. It can be found by trial and error method. The IRR method can be summarized as seen in Eq. (1). Because of the social benefits of this project, the energy utilization price at which the IRR value is equal to zero was determined in this assessment.

$$
\sum_{n=0}^{N} \frac{\mathrm{NCF}_{n}}{(1+r)^{n}}=0
$$

where $n$ is the number of year, NCF the net cash flow in the $n$th year, $N$ the life of the investment and $r$ is the discount rate.

The money related to construction cost was assumed as paid at the accrual date while operating cost and revenues were paid at the end of month throughout the analysis. The revenues were assumed as earned at the end of a month in the calculations. By using daily interest rates, end of month value of an accrual was calculated. Then, end of year values were calculated by using monthly interest rates. End of year calculations were begun with finding the end of 1996 value. These calculations were repeated up to 2003. The future values of all past cash flows were calculated by using interest rates of the Central Bank of Turkish Republic. The future value of money (FV), with respect to interest rate $(i)$ and present value $(\mathrm{PV})$, was calculated by Eq. (2).

$\mathrm{FV}=\mathrm{PV}(1+i)^{n}$

where $n$ is the total number of corresponding periods.

The cost of renovation was also taken into consideration to complete life cycle cost analysis. Renovation in piping network was anticipated due to corrosion and leakage problem in the energy distribution network. It was assumed that $75 \%$ of the piping network would be replaced after 5 years while the remaining would be replaced after 10 years. It was considered that glass-fiber reinforced polyester composite pipes having a polyurethane heat isolator and a fiberglass-reinforced plastic cover would be installed instead of carbon steel pipes. It was also accepted that the pumps would be changed after 10 years. The life of the pipe was assumed as 15 years in depreciation of the future renovations. The salvage values of the equipment were taken as the revenue at the end of their lives. The yearly tax paid in 2002 was used to determine the future tax as being proportional with the net income. In depreciation calculations, the values of equipment were allocated as expenses over their depreciable lives. Double declining balance depreciation method was used in this assessment. This method involves applying a depreciation rate against the undepreciated balance that was named as book value, rather than the original cost $[17,18]$.

First, the IRR value for the constant yearly operating cost was determined in this research. Then, the case was investigated for different monthly charges while the operating cost was an invariable parameter. Fifty-six different pricing scenarios in which the monthly energy utilization price was changed from US\$ 17 to 72 were taken into consideration in this stage. On the other hand, variable energy utilization price was also investigated with regard to average and the last increasing rates, which were $16 \%$ and $39 \%$, respectively. These scenarios were named as A1-A4. In scenarios of A1 and A2, energy utilization price was increased by $16 \%$ each year up to 2011. Then, the price was taken constant up to end of the investment life. In scenario A2, the institutional energy utilization charges considered in scenario A1 were increased

Table 3

Cash flow components

\begin{tabular}{|c|c|c|c|}
\hline No. & Item & $\begin{array}{l}\text { Total } \\
\text { amount (US\$) }\end{array}$ & $\begin{array}{l}2003 \\
\text { values (US\$) }\end{array}$ \\
\hline & Capital cost & 14431307 & 23598821 \\
\hline A & Surface cost & & \\
\hline 1 & Construction cost & 12264947 & 20269431 \\
\hline $\mathrm{a}$ & Construction of pumping station & 112123 & \\
\hline $\mathrm{b}$ & Transport of materials & 401302 & \\
\hline $\mathrm{c}$ & Electricity installation & 214370 & \\
\hline $\mathrm{d}$ & $\begin{array}{l}\text { Installation of heating equipment } \\
\text { used in pumping stations }\end{array}$ & 56338 & \\
\hline e & $\begin{array}{l}\text { Installations in wellhead housings, } \\
\text { buildings, and pumping stations }\end{array}$ & 329160 & \\
\hline f & Excavation & 606173 & \\
\hline $\mathrm{g}$ & Sanitary installations & 6194 & \\
\hline $\mathrm{h}$ & Automatic control & 622 & \\
\hline $\mathrm{i}$ & Installation of transformer & 32007 & \\
\hline $\mathrm{j}$ & $\begin{array}{l}\text { Piping networks, pumps, heat } \\
\text { exchangers, compensators etc. }\end{array}$ & 10140528 & \\
\hline $\mathrm{k}$ & Other materials & 366130 & \\
\hline 2 & Additional investment & 664409 & 698026 \\
\hline $\mathrm{a}$ & In 2001 & 283540 & 311970 \\
\hline $\mathrm{b}$ & In 2002 & 380869 & 386056 \\
\hline B & Subsurface cost & 1501952 & 2485024 \\
\hline 1 & Drilling costs up to 2001 & 1358236 & \\
\hline 2 & Drilling costs in 2002 & 143716 & 146340 \\
\hline $\mathrm{C}$ & Operating cost & 3046732 & 3462096 \\
\hline D & Revenues & 8607041 & 11039167 \\
\hline 1 & Connection lines & 4011960 & 5584181 \\
\hline 2 & Fix & 4411920 & 5254183 \\
\hline 3 & Bank interest over surplus & 183161 & 200803 \\
\hline $\mathrm{E}$ & Tax & 82547 & \\
\hline
\end{tabular}




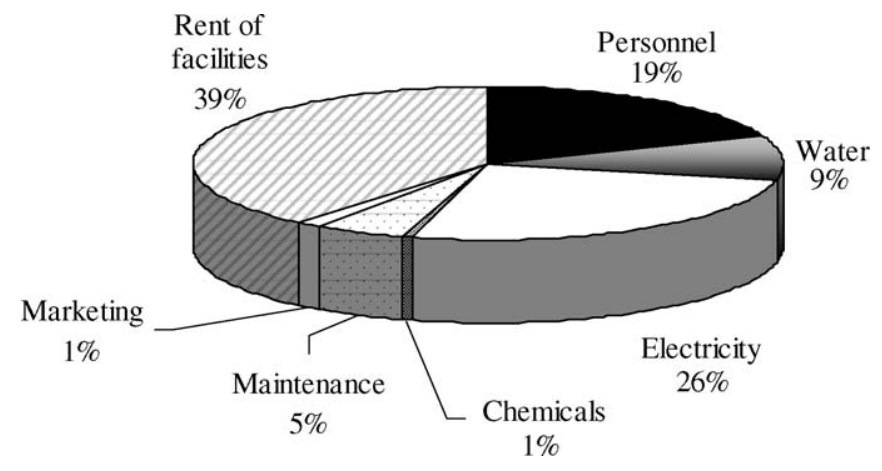

Fig. 4. The operating cost percentages.

by $50 \%$. In scenario A3, energy utilization price was increased by $39 \%$ up to 2005 and $16 \%$ from 2006 to 2010 . In scenario A4, energy utilization price was increased by $39 \%$ up to 2006 and $16 \%$ from 2007 to 2010 . All the prices were remained constant after 2010 in scenarios of A3 and A4. Afterward, the IRR calculations were done for thirteen different yearly costs due to the uncertainty in future operating cost [19]. End of year value of the operating cost in 2002 was decreased and increased, alternatively, from $5 \%$ to $30 \%$ by $5 \%$ in each step. Each operating cost scenario had sub scenarios according to energy utilization prices. Therefore, 780 different scenarios were created and the IRR values were calculated for those scenarios.

\section{Results and conclusions}

The development of geothermal energy should be determined not only by geological factors but by socio-economic ones as well. An economic assessment is a significantly strenuous task especially at the commencement phase of a geothermal district heating investment. Geothermal district heating system investments are characterized by a high capital and relatively low operation and maintenance costs.

The year 2003 values of all cash flows are given in Table 3. The heated area by geothermal energy is $1,150,000 \mathrm{~m}^{2}$ in this research. Energy requirement in 2002 was $176,664,816 \mathrm{~kW}$. Therefore, it is found that a household required $154 \mathrm{~kW} / \mathrm{m}^{2}$ unit

Table 4

Energy utilization prices that make the IRR zero for different operating costs

\begin{tabular}{ll}
\hline Operating cost (US\$) & $\begin{array}{l}\text { Suggested energy } \\
\text { utilization price (US\$) }\end{array}$ \\
\hline 784853 & 46.1 \\
840914 & 47.7 \\
896975 & 49.2 \\
953036 & 50.8 \\
1009096 & 52.4 \\
1065157 & 53.9 \\
1121218 & 55.5 \\
1177279 & 57.0 \\
1233340 & 58.6 \\
1289401 & 60.1 \\
1345462 & 61.7 \\
1401523 & 63.2 \\
1457584 & 64.8 \\
\hline
\end{tabular}

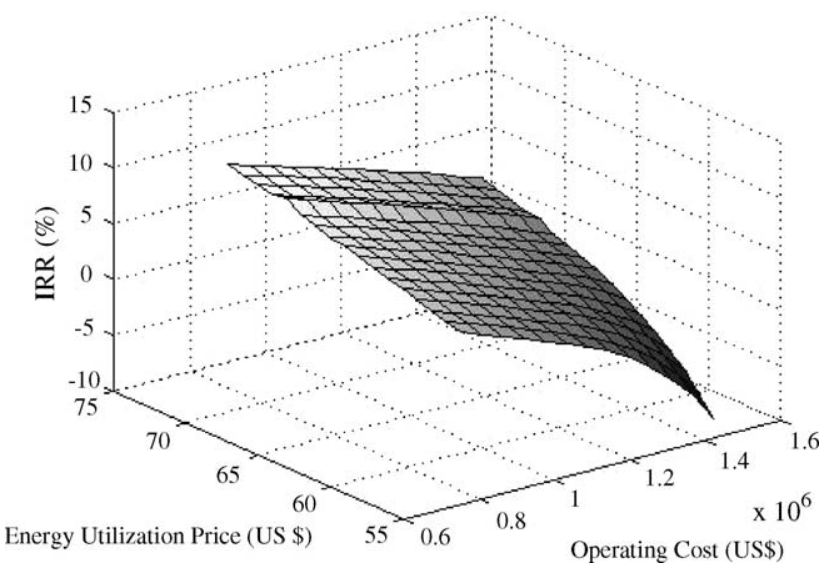

Fig. 5. The IRR values vs. energy utilization prices and yearly operating cost.

energy in 2002. The capital and operating costs of the district heating system are 20.5 and 0.98 US $\$$ per $\mathrm{m}^{2}$ household, respectively. Operating cost in Balcova-Narlidere geothermal district heating system is shown in Fig. 4.

In this research, economic assessment is concluded with the calculation of energy utilization prices. Because of the social concerns, the Balcova-Narlidere geothermal district heating system is accepted as a public investment. The social benefits of this project are more important than making profits. Therefore, energy utilization prices are calculated according to the discount rates that make the net present value of all cash flows zero. The impacts of changes in potential operating cost and revenues on the IRR values are demonstrated. Energy price is suggested for different operating costs in Table 4. Fig. 5 shows the IRR values versus energy utilization prices and yearly operating costs.

As it is seen from Fig. 6 that the scenarios A1 and A2 are acceptable ones, if the operating costs were decreased $30 \%$ and $25 \%$, respectively. The scenarios A3 and A4 can be also acceptable for the current operating cost.

It is found that, if the energy utilization price is US\$ 55.5 per $100 \mathrm{~m}^{2}$ household, the investment is socially feasible with the year 2002 operating cost. For the energy utilization price lower than this value, the investment needs to be subsidized by the

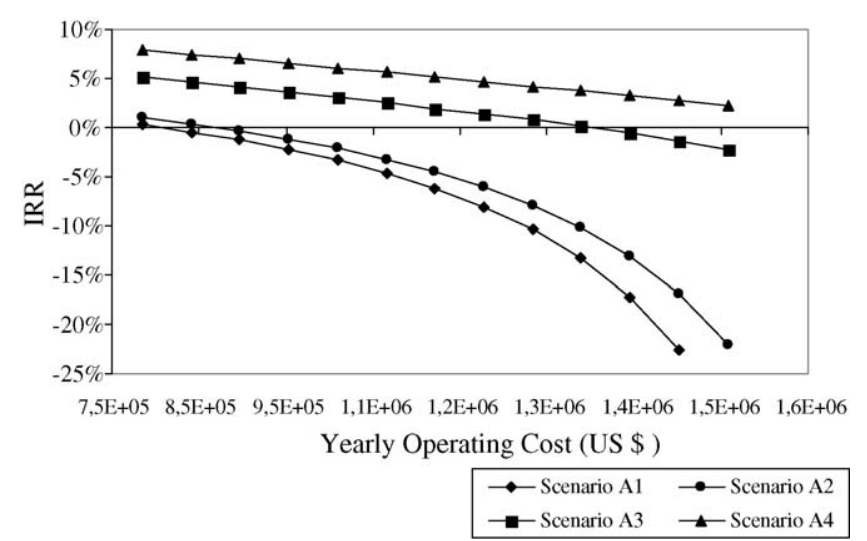

Fig. 6. The IRR values as a function of operating costs in alternative pricing scenarios. 
local government. In order to prevent this subsidy, abovementioned energy utilization price should be applied or the operating cost should be decreased, remarkably.

\section{References}

[1] M.H. Dickson, M. Fanelli, Geothermal Energy, John Wiley and Sons, 1995.

[2] R. Harrison, N.D. Mortimer, O.B. Smarason, Geothermal Heating: A Handbook of Engineering Economy, Pergamon Press, 1990.

[3] W.J. Lund, P.J. Lienau, B.C. Lunis, Geothermal Direct Use Engineering and Design Guidebook, Geo-Heat Center, 1998.

[4] R.G. Bloomquist, Geothermal District Energy System Analysis, Design, and Development, European Summer School on Geothermal Energy Applications, Oradea, Romania, 2001.

[5] K. Rafferty, Selected Cost Considerations for Geothermal District Heating in Existing Single - Family Residential Areas, Quarterly Bulletin, vol. 17, No: 3, Geo-Heat Center.

[6] S. Simsek, An overview of geothermal developments in Turkey, in: Proceedings of ITIT Symposium on Geothermal in Asia, February 28March 1, Tokyo, Japan, (2001), pp. 17-23.

[7] C. Kissel, M. Jamet, C. Laj, in: J.E. Dixon, A.H.F. Robertson (Eds.), Paleomagnetic Evidence of Miocene and Pliocene Rotational Deformation of the Aegean Area, vol. 17, The Geological Evolution of the Mediterranean Geology Society Special Publication, 1984, pp. 669-680.

[8] J.A. Jackson, D. McKenzie, Rates of active deformation in the Aegean Sea and surrounding areas, Basin Research 1 (1988) 121-128.
[9] W.J. Lund, D.H. Freestone, World-wide direct uses of geothermal energy, Geothermics 30 (2001) 29-68.

[10] U. Serpen, Hydrogeological investigations on Balçova geothermal system in Turkey, Geothermics 33 (3) (2004) 309-335.

[11] W.J. Lund, Large Downhole Heat Exchanger in Turkey and Oregon, vol. 3, Geo-Heat Center, 1999 (Quarterly Bulletin) pp. 17-19.

[12] A.B. Erdogmus, Economic Assessment of Balcova-Narlidere Geothermal District Heating System, M.Sc. Thesis (Supervisor: B. Ozerdem, M. Toksoy), Graduate School of Engineering and Sciences of Izmir Institute of Technology, Izmir, Turkey, 2003.

[13] A.C. Sener, M. Toksoy, N. Aksoy, Importance of Load Based Automatic Control in Geothermal Energy Systems, IFAC Automatic Systems for Building the Infrastructure in Developing Countries, Istanbul, Turkey, 2003.

[14] M. Kanoglu, Y.A. Cengel, Economic evaluation of geothermal power generation, heating, and cooling, Energy 24 (1999) 501-509.

[15] V. Stefansson, Economic Aspects of Geothermal Development, Internal Workshop on Direct Use of Geothermal Energy, Ljublijana, Slovenia, 1999.

[16] J.A. Sepulveda, W.E. Souder, B.S. Gottfried, Theory and Problems of Engineering Economy, McGraw-Hill Inc., 1984.

[17] E.L. Grant, W.G. Ireson, R.S. Leavenworth, Principles of Engineering Economy, 8th ed., John Wiley and Sons Inc., Canada, 1990.

[18] C.S. Park, Contemporary Engineering Economics, Addison-Wesley Publishing Company, USA, 1993.

[19] P. Jovanic, Application of sensivity analysis in investment project evaluation under uncertainty and risk, International Journal of Project Management 17 (4) (1999) 217-222. 